\title{
JUDGE'S DECISION ON WORK TERMINATION DISPUTE IN INDONESIA AFTER CONSTITUTIONAL COURT DECISION NUMBER 37/PUU-IX/2011 $\Omega$
}

\author{
Neni Vesna Madjid, ${ }^{1}$ Saldi Isra, ${ }^{2}$ Kurnia Warman ${ }^{2}$ and Mardenis ${ }^{2}$ \\ ${ }^{1}$ Candidate Doctor from Doctoral Program of Law Faculty, Andalas University, Padang - Indonesia \\ E-mail: nenivesna@gmail.com \\ ${ }^{2}$ Postgraduate Doctoral Program Faculty of Law, Andalas University, Padang - Indonesia
}

\begin{abstract}
Testing the provision of Article 155 section (2) Law Number 13 of 2003 on Manpower has been decided by the Constitutional Court (CC) through decision Number 37/PUU/IX/2011. Prior to the Constitutional Court decision, there are many various interpretations of undetermined clause. The Constitutional Court firmly states that the undetermined clause must be interpreted as "having a permanent legal force ". This study aims to analyze how the judges dismissed dispute of work termination cases in Indonesia after the decision. The research applied juridical normative method by using secondary data literature such as legal documents, previous studies and other references which are relevant to the judges' decision within the Supreme Court after the Constitutional Court decision. Based on the analysis temporary result, the judges within the Supreme Court in 3 regions (Padang, Pekanbaru and Jakarta Pusat) and the Supreme Court itself are not practically guided by the Constitutional Court decision. It obviously results in the lack of legal certainty for the parties, especially workers.
\end{abstract}

Keyword: Constitutional Court, Industrial Relation Court, interpretation, Supreme Court.

\section{Abstrak}

Pengujian ketentuan Pasal 155 ayat (2) UU No. 13 Tahun 2003 tentang Ketenagakerjaan telah diputus oleh Mahkamah Konstitusi (MK) melalui putusan No. 37/PUU/IX/2011. Sebelum adanya putusan MK, penafsiran tentang klausula belum ditetapkan sangatlah beragam. MK dengan tegas menyatakan bahwa klausula belum ditetapkan haruslah dimaknai dengan "telah memiliki kekuatan hukum yang tetap". Penelitian ini bertujuan untuk menganalisis bagaimana hakim memutus sengketa perselisihan pemutusan hubungan kerja di Indonesia pasca putusan MK tersebut. Metode penulisan yang digunakan adalah yuridis normatif menggunakan literatur data sekunder berupa dokumen hukum, studi sebelumnya dan referensi lainnya yang relevan dengan putusan hakim di lingkungan Mahkamah Agung (MA) pasca putusan MK tersebut. Hasil analisis sementara, dalam praktiknya hakim di lingkungan MA pada 3 wilayah (Padang, Pekanbaru dan Jakarta Pusat) maupun MA sendiri tidak berpedoman pada putusan MK tersebut. Ketidakberpedomanan itu jelas membawa dampak tidak adanya kepastian hukum bagi para pihak terutama pekerja.

Kata kunci: Mahkamah Agung, Mahkamah Konstitusi, penafsiran, Pengadilan Hubungan Industrial

\section{Introduction}

According to Article 24 section (2) Constitution 1945, judiciary power is conducted by two agents which are Supreme Court and Constitutional Court. ${ }^{1}$ Therefore, the reformation in

\footnotetext{
$\Omega$ This article is a part of the author's dissertation entitled "Perlindungan Hukum terhadap Pekerja dalam Perselisihan Pemutusan Hubungan Kerja di Indonesia" in Postgraduate Doctoral Program of Law Faculty, Universitas Andalas with Decision Letter Number 442/UN.16/PP.S3/ 2016 on September 8, 2016 about Research permit to collect data.
}

terms of law (Constitution 1945 Amendment) has determined that Supreme Court is no longer the only one judiciary power, but it is just one of the judiciary powers. ${ }^{2}$ Supreme Court has a strategic position especially in law and state ad-

\footnotetext{
1 Sri Soemantri, 2004, Kedudukan, Fungsi dan Peran Konstitusi dalam Sistem Ketatanegaraan dalam Hukum dan Kuasa Konstitusi, Catatan-catatan untuk pembahasan RUU MK, Jakarta: KRHN, p. 18.

2 Titik TriWulan Tutik, 2010, Kontruksi Hukum Tata Negara Indonesia Pasca Amandemen UUD 1945, Jakarta: Kencana Prenada Media Group, p. 210.
} 
ministration: first, to conduct a judicature in order to enforce the law; second, to adjudicate in appellate level; third, testify the regulations under the law; and fourth, to have any authority given by the law. ${ }^{3}$ Meanwhile, Constitutional Court in state administration is constructed: first, as constitutional guide that enforces constitutional justice among society. Second, to encourage and to guarantee the constitution to be respected and implemented consistently and responsibly by all of state components. Third, in the middle of the constitutional system weakness, it functions as an interpreter to maintain the constitutional spirit and take a part in the state and society sustainability. ${ }^{4}$

Law Number 13 year 2003 on Manpower (hereafter abbreviated as Manpower Law) stipulation drew many criticisms and refusals from Labor Union ${ }^{5}$ since the stipulation was initiated by the government through Ministry of Manpower and Transmigration which at that time was held by Jacob Nuwawea. Three months after the law legalization on 18th June 2003, the Legal Aid Institute (LBH) Jakarta filed a claim to the Manpower Law implementation through Supreme Court which then appeared in Constitutional Court trial. ${ }^{6}$

Not only the Manpower Law implementation, but the articles were also issued by manpower observer. One of them is the stipulation of Article 155 Section (2) Manpower Law that was requested to be testified in Constitutional court by three workers as well as labor issues observers (drg. Ugan Gandar, Ir. Eko Wahyu, and Ir. Rommel Antonius Ginting) on 1st June 2011. The article states:

"As long as there is no decision from the institution for the industrial relations disputes settlement, the entrepreneur and the worker/laborer must keep on performing their obligations."

The applicants (observers) asked for the constitutional interpretation upon the Article

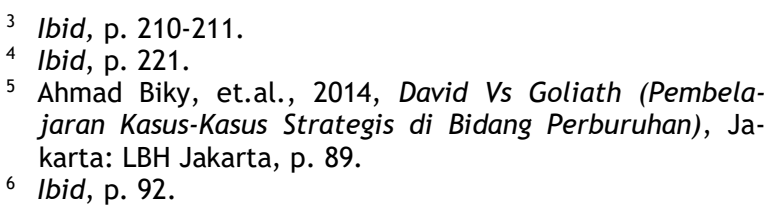

since its implementation invoked law uncertainty that against Article $28 \mathrm{D}$ section (1) and (2) of Constitution 1945. By means, Article 155 section (2) Manpower Law along the phrase "undetermined" is interpreted until there is Industrial Relation Court decision that has permanent legal power (inkracht).

Finally, Constitutional Court through the decision Number 37/PUU/IX/2011 accepts the applicants' claim with the decisions as follows:

1. The Phrase "undetermined" in Article 155 Section (2) Law Number 13 Year 2003 on Manpower (Indonesian State Gazette Year 2003 Number 39, Supplement of Indonesian State Gazette Number 4279) is against the Constitution 1945 as long as it has not been interpreted without permanent legal power;

2. The phrase "undetermined" in Article 155 Paragraph (2) Law Number 13 Year 2003 on Manpower (Indonesian State Gazette Year 2003 Number 39, Supplement of Indonesian State Gazette Number 4279) has no legal power as long as it is not interpreted as without permanent legal power;

Based on the explanation above, in general, the issue in this journal is how the judge settles the work termination dispute in Indonesia after the Constitutional Court decision Number 37/PUU$I X / 2011$. This issue is important to give law certainty for all the parties especially the workers.

\section{Research Method}

This research is normative law research. It sets law as a norm construction. ${ }^{7}$ The referred norm system is all about principles, norm, regulation convention, court decision, agreement and doctrine. ${ }^{8}$ The data source of this research is the issue in The Industrial Relation Court (IRC) in Padang District Court, The IRC on Pekanbaru District Court and Central Jakarta District Court in 2011 until 2015 as well as the official website of Indonesian Supreme Court

\footnotetext{
7 H. Salim dan Erlies Septiana Nurbaini, 2013, Penerapan Teori Hukum pada Penelitian Thesis dan Disertasi, Jakarta: PT. Raja Grafindo, p. 13.

8 Ibid, p. 34.
} 
that provides online directory decision on http://www.putusan.mahkamahagung.go.id.

The research methods are qualitative and quantitative methods. By quantitative process, the researcher can answer the question on how the judge consideration especially judges of Supreme Court in dismissing the layoffs dispute especially related to process wage after the Constitutional Court Decision Number 37/PUU-IX/ 2011. Qualitatively, the researcher conducts deeper understanding by taking the decisions related to the process wage in 3 (three) IRCS and Supreme Courts.

\section{Discussion \\ Constitutional Court Authority and Judge In- terpretation}

The existence of Constitutional Court in Indonesia becomes one of Indonesian constitutional law discourses. ${ }^{9}$ Furthermore, the Constitution 1945 provides authority to Constitutional Court to become constitutional guide. ${ }^{10}$ Constitutional Court has an authority to testify the politics product which is law from People's Representative Council (DPR) that is considered against Constitution 1945. The authority is the most conducted authority by Constitutional Court. In Dutch Literature, the authority is known as toetzingrechts or "rights to test the law". ${ }^{11}$ In Allen and Thomson view, there are several toetzingrechts which are toetzingrechts as legislative review, toetzingrechts as executive review, and toetzingrechts as judicial review. ${ }^{12}$ In this case, Sri Sumantri explains that rights to testify material matter is an authority to examine and to evaluate whether the regulation content is convenient with the upper law or not and whether a particular authority (verordenende macht) has a right to set out

9 Nanang Sri Darmadi, "Kedudukan dan Wewenang Mahkamah Konstitusi dalam Sistem Ketatanegaraan Indone-sia," Jurnal Hukum Vol XXVI, No.2, Agustus 2011, p. 668.

${ }^{10}$ Aninditya Eka Bintari, "Mahkamah Konstitusi sebagai Negative Legislator dalam Penegakan Hukum Tata Negara", Jurnal Pandecta, Vol 8 No. 1, January 2013, p. 87.

11 Yance Arizona, "Dibalik Konstitusional Bersyarat Putusan Mahkamah Konstitusi", JurnalKonstitusi PUSaKO Universitas Andalas, Vol. I No. 1, November 2008, p. 7.

12 Saldi Isra dan Feri Amsari, "Perubahan Konstitusi Melalui Tafsir Mahkamah Konsitusi", JurnalKonstitusi PUSaKO Universitas Andalas, Vol. I No. 1, November 2008, p. 113. particular regulation or not. ${ }^{13}$ The judiciary authority division of Supreme Court and Constitutional Court does not mean there is dualism judiciary power but it more emphasizes on each function. Supreme Court more emphasizes on its function through judiciaries that end up in Supreme Court while Constitutional Court emphasizes on the judiciary function in politics. ${ }^{14}$

The judicial review authority has caused an abstract authority or created a new authority which is to conjugate a constitution. ${ }^{15}$ The interpretation which is known by the word "hermenutik" or hermeneutics is a parable from English which is "hermeneutic" (adjective) that is translated into a condition or characteristic in an interpretation, while hermeneutics(noun) contains three meanings in an interpretation science; first, it is to know the meaning in the author's statements and words and a specific interpretation that points out text or holy book interpretation. ${ }^{16}$ However, some people said that interpretation comes from the Arabic word 'tafsir' which means explain or state. The word is taken from the word tafsirrah which refers to tool used by doctor to know patient's disease. The use of tafsir sticks to the meaning search in Quran. In interpreting the Quran meaning, the old muftis (Syafi'i Maliki, Hanafi, Ahmad Bin Hambal, Alghazali, Ibnu Timiyyah, Muhammad Abduh, Rasyid Rida, and others) used the supporting science such as the Lughat science, Nahwu, Tashrif Balaghah, Usul Fiqih, as well as Asbabun Nuzul. ${ }^{17}$

The law interpretation is a law discovery method. It is a law discovery method in which the rule exists but it is unclear to be implemented in the actual case. However, it might also happen if the judge has to inspect and try a

13 Saldi Isra,"Peran Mahkamah Konstitusi dalam Penguatan Hak Asasi Manusia di Indonesia, Jurnal Konstitusi, Vol. 11 No. 3, September 2014, p. 420.

${ }^{14}$ Nanang Sri Darmadi, op.cit, p. 30.

15 Saldi Isra dan Feri Amsari, op.cit, P. 120.

${ }^{16}$ Alef Musyahadah, "Hermeneutika Hukum sebagai Alternatif Metode Penemuan Hukum bagi Hakim untuk Menunjang Keadilan Gender", Jurnal Dinamika Hukum, Vol. 13 No. 2, May 2013, p. 298.

17 Tanto Lailam, "Penafsiran Konsitusi Dalam Pengujian Konstitusionalitas Undang-undang terhadap Undang-Undang Dasar 1945“, Jurnal Media Hukum, Vol. 21 No. 1, June 2014, p. 91. 
case which do not have a specialized rule. ${ }^{18}$ The law discovery method consists of: ${ }^{19}$ Firstly, the law interpretation including: ${ }^{20}$ grammatical, historical, systematical, and sociological interpretations. The historical interpretation is divided into two interpretation sectors. First, the historical interpretation based on rules. Second, the interpretation based on law institution, or its history; second, the law construction that consists of: The Argumentum Peranalogium (analogical), the Argumentum a Contrario, and the constricting methodology of a rule of law which is too abstract, wide, and general so that it can be implemented in a certain case.

Therefore, the judge's decision quality has an important impact to the justice institution authority and the credibility. ${ }^{21}$ Nevertheless, the result of the law discovery method will arise a qualified decision, and caustically, it should be based on the law certainty, justice, and benefits principles. ${ }^{22}$

\section{Material Test Analysis of Article 155 section (2) on Constitution 1945}

The case decision Number 37/PUU/IX/ 2011 is the decision model which calls off and states that the Article 15 section (2) Manpower law is legally Null and Void. The decision does have a wide and huge impact. It does not only give benefits for the justice seekers, but also can potentially cause a legal vacuum, ${ }^{23}$ legal disorder, ${ }^{24}$ even buying time for the law ma-

${ }^{18}$ Arif Hidayat, "Penemuan Hukum Melalui Penafsiran Hakim dalam Putusan Pengadilan", Jurnal Pandecta, Vol. 8 No. 2, July 2013, p. 155.

19 Yosef M Monteiro, "Putusan Hakim dalam Penegakan Hukum Di Indonesia”, Jurnal Hukum Pro Justitia, Vol. 25 No. 2, April, 2007, p.136.

${ }^{20}$ Saldi Isra dan Feri Amsari, op.cit, p. 116.

21 Agus Priono, "Penerapan Teori Penafsiran Hukum oleh Hakim sebagai Upaya Perlindungan Hukum Terhadap Notaris (Studi Atas Putusan Hakim Terhadap Tindak Pidana Akta Otentik)", Jurnal Pasca Sarjana Hukum UNS, Vol. V No. 2, July-December 2017, p.120.

22 Josef M Monteiro, "Putusan Hakim dalam Penegakan Hukum di Indonesia", Jurnal Hukum Projustitia, Vol 25 No. 2, April 2007, p. 137; See also Arief Hidayat, op.cit, p. 154.

${ }^{23}$ Topane Gayus Lumbuun, "Tindak Lanjut Putusan MK o-leh DPR RI”, Jurnal Legislasi Indonesia, Vol. 6 No. 3, September 2009, p. 498.

${ }^{24}$ Refly Harun, "Implikasi Putusan MK Terhadap Proses Legislasi”, Speech, in Regulations Formulation speech with ker. ${ }^{25}$ The decision is, however, considered to be constitutive by looking its variety. Deklatoir means that the judge's decision is only to state a law. Being constitutive means that a de-cision states about the legal condition vacuum or create the new one. ${ }^{26}$ Therefore, when a constitution states that a law binds due to against Constitution 1945, the decision will automatically create a new legal condition. ${ }^{27}$ However, as a condition that public should know as it is explained in Article 57 section (3) Law Number 24 Year 2003, the supreme court's decision that grants an appeals must be recorded in State Gazette within 30 days since the decision is declared. ${ }^{28}$

The Constitutional judge panel through their decision has found law discovery to fill the legal vacuum. In line with Sens Clair doctrine, the law discovery conducted by the constitutional judge panel is based on the existing yet unclear rules. Both Manpower law and Industrial Relations Dispute Settlement law have managed the wages should be paid by the employer to the workers along the Work Termination process. However, these laws and their enforcement rules do not regulate clearly how long the wages must be paid. In addition, the Supreme Court make their finding that the phrase interpretation uncertainty against the Article $28 \mathrm{sec}$ tion (1) and (2) Constitution 1945. ${ }^{29}$ According to authors, the Supreme Court's judges, in stipulating the decision Number 37/PUU/IX/2011, have conducted a systematical interpretation because they have interpreted the law as a part of the whole law system. It means that none of the the law rules can be interpreted as if it

Constitutional Court Decision Implementation on Law legislation process theme, Friday, December 3, 2010.

25 Maruaraar Siahaan ,"Peran MK Dalam Penegakan Hukum Konstitusi", Jurnal Hukum, Vol. 16 No. 3, 2009, p. 358.

${ }^{26}$ Maruarar Siahaan, Ibid., p. 197-199.

27 Denny Indrayana dan Zainal Arifin Mochtar, “Komparasi Sifat Mengikat Putusan Judicial Review Mahkamah Konstitusi dan Pengadilan Tata Usaha Negara", Jurnal Mimbar Hukum, Vol 19 No. 3, October 2007, p. 439-440.

${ }^{28}$ Amrizal J.Prang, 2011, Implikasi Hukum Putusan Mahkamah Konstitusi, Kanun Jurnal Ilmu Hukum, Vol. XIII No. 53, April, 2011, p. 85

29 Vidya Prahassacitta, "Makna Upah Proses Menurut Mahkamah Konsitusi Dibandingkan Dengan Beberapa Putusan Mahkamah Agung, kajian Putusan MK Nomor 37/PUU-IX/ 2011", Jurnal Yudisial Vol 6 No 3 December 2013, p. 213. 
stands alone. However, it should be well understood in accordance with the variety of other rules. In this case, the Article 155 section (2) Manpower Law is connected with the Article 56 juncto Article 109 and 110 Law Number 2 Year 2004 on Industrial Relations Dispute Settlement.

Based on the research of some decisions in three IRC (PHI) and Supreme Court that deal with the process wage after the existence of Supreme Court decision Number 37/PUU/IX/ 2011, the data collected are as follows:

Table 1. IRC Court Decision after Supreme Court Decision

\begin{tabular}{ll}
\hline \multicolumn{1}{c}{ At IRC level } & $\begin{array}{c}\text { At Cassation/Supreme } \\
\text { Court level }\end{array}$ \\
\hline Case Number & Case Number 172 \\
$58 /$ PHI.G/2011/PN.JKT. & K/PDT.SUS/2012 is \\
PST is granted in 6 months & $\begin{array}{l}\text { granted in } 1 \text { month } \\
\text { Case Number } 172\end{array}$ \\
Case Number & K/PDT.SUS-PHI/2013 is \\
030/G/2012/PHI.PBR is & granted in 6 months \\
granted in 8 months & Case Number 239 \\
Case Number 11/PDT.Sus- & K/PDT.SUS-PHI/2015 is \\
PHI/2014/PN.Pdg is & granted in 6 months \\
granted in 9 months & \\
\hline Source: IRC Padang, Pekanbaru, Central Jakarta and Supre- \\
me Court
\end{tabular}

The above table can be elaborated as follows: First, Case Number 58/PHI.G/2011/PN. JKT.PST at the IRC in Central Jakarta District Court which was decided on July 14, 2011 granted the wage process from January 2010 to June 2010 (6 months). Yet, at the cassation level in Supreme Court according to Decision Number 172 K/PDT.SUS/2012, the wage process was only granted for one month only because the Plaintiff has requested the Defendant to have his/ her work terminated by letter dated on January 6, 2010 and thereafter not to be employed. Therefore, according to Article 93 section 1 Manpower Law and Article 100 Industrial Relations Dispute Settlement Act, the work termination ended up on January 2010. Second, Case Number 030/G/2012/PHI.PBR at the IRC in Pekanbaru District Court which was decided on December 21, 2012 to grant the wage process for 8 months. However, at the Cassation level in the Supreme Court according to Decision No. 172K/PDT.SUS-PHI/2013 it was only granted for 6 months; Third, Case Number 11/PDT.SusPHI/2014/PN.Pdg in the IRC of Padang District Court which was settled on January 12, 2015, it was granted 9-month wage process (from April 2014 to December 2014). Yet, at the Supreme Court according to Decision 239 K/PDT.SUS-PHI/ 2015, it was only granted for 6 months only with consideration of the time length of the settlement process in accordance with Law Number 2 Year 2004 on Industrial Relations Dispute Settlement which takes approximately 6 (six) months.

The 3 cases been settled by the IRC and the Supreme Court judges, it can be seen that the judges have disregarded the Constitutional Court decision. In fact, if it is associated with the Constitutional Court authority as regulated in Article 24 C Section (1) Constitution 1945, it is stated that the Constitutional Court has the authority to adjudicate constitution cases at the first and final level of which the decision is final... ${ }^{30}$ Furthermore, the provisions of Article 10 Law Number 24 Year 2003 on Constitutional Court determines the Constitutional Court decision is final and binding. Final means last of the checks series while binding is defined as "solidify, unite". ${ }^{31}$ It means that there is no more possibilities to take legal efforts as known to be conventional court, appeal, cassation and even review. ${ }^{32}$ Article 10 section (1) Law Number 8 Year 2011 on the Law amendment Number 24 Year 2003 on the Constitutional Court also explicates that the Constitutional Court's decision has directly obtained a permanent legal force since it was pronounced and no legal effort can be taken. ${ }^{33}$ It means the case decision Number 37/PUU/IX/2011 has been binding since September 6, 2011. In addition, the Constitutional Court judge's decision is erga omnes. It implies that the decision has a binding power, which does not only bind the applicant (the workers), and the employer, IRC's and Supreme Court's judges but also all parties, state institutions and legal entities in the Indonesian territory. In

${ }^{30}$ Fajar Laksono Soeroso, “Aspek Keadilan dalam Sifat Fi-nal Putusan Mahkamah Konstitusi, Jurnal Konstitusi, Vol. 11 No. 1, March 2014, p. 73.

31 R. Nurman Ardian K, Et.Al., "Rekonstruksi Terhadap Si-fat Final Dan Mengikat Putusan Mahkamah konstitusi, Jurnal FIAT JUSTITIA, Vol. 10 Issue 4, October-December 2016, p. 791-792.

32 Ibid, p.792

${ }^{33}$ Steven Supratio, "Daya Ikat Putusan Mahkamah Konstitusi Tentang Testimonium De Auditu dalam Peradilan Pidana”, Jurnal Yudicial, Vol. 7 No. 1 Year 2014, p.43. 
addition, the Constitutional Court judges in this case are said to be negative legislators. ${ }^{34}$ The term negative legislator was firstly introduced by Hans Kelsen in his General Theory of Law and State. ${ }^{35}$ This means that authority relates to the norms annulment that exist in a law and against the constitution. ${ }^{36}$ In this case, the provisions of Article 155 section (2) Law Number 13 Year 2003 as long as with the phrase "undetermined", it is declared to against the Constitution 1945 and there is no binding power. By this model, the Constitutional Court is also a part that might affect the legislative process in the legislative institution. ${ }^{37}$ Furthermore, if we look at the provisions of Article 53 Constitutional Court Law, it states that "The Constitutional Court shall inform the Supreme Court about the application for judicial review within 7 (seven) working days since the application is recorded in the Constitutional Case Registration Book". According to the authors, this provision means that the Supreme Court and its subordinate courts recognize that there are articles or laws which are being examined in the Constitutional Court. Thus, when there are cases handled by the Supreme Court and the subordinate courts in deciding cases or disputes relating to sections or the laws tested by the Constitutional Court, they shall be guided by the Constitutional Court decision. However, practically, the three IRCs and the Supreme Court, especially the Court's decision Number 37/PUU/IX/2011 is considered as the guidance which results in a legal uncertainty for the parties, especially for the workers.

\section{Conclusion}

The provision of Article 155 section (2) Law Number 13 Year 2003 on Manpower filed by

\footnotetext{
${ }^{34}$ Rian Van Frits Kapitan, "Kekuatan Mengikat Putusan Constitusional Review Mahkamah Konstitusi terhadap Mahkamah Agung", Jurnal Masalah-masalah Hukum, Vol. 44 No. 4, October 2015, p. 515.

${ }^{35}$ Pan Mohamad Faiz, "Relevansi Doktrin Negative Legislator", Majalah Konstitusi, No 108, February 2016, p. 6-7.

${ }^{36}$ Mei Susanto, "Kewenangan Mahkamah Kontitusi sebagai Negative Bugdeter dalam Pengujian Undang-undang Anggaran Pendapatan dan Belanja Negara, Jurnal Kons-titusi, Vol. 14 No. 4, Desember 2017, p. 729.

37 Saldi Isra, n.d., Negative Legislator, available on website: https://www.saldiisra.we.id/index.php/21-makalah/ makalah1/302-negative-legislator.html, accessed on Februari $17^{\text {th }}, 2018$
}

the worker, as long as the phrase "has not been determined is declared to have no binding force as long as it is not interpreted to have permanent legal force with the Constitutional Court's decision Number 37/PUU-IX/2011. Nevertheless, in the practice, the IRC's Judge in Padang District Court, the IRC's Judge in Pekanbaru District Court, the IRC's Judge in the Central Jakarta District Court and the Supreme Court's Judge do not based on and disregard the Constitutional Court decision which then results in a decision with no legal certainty related to the wage process in work termination.

\section{Suggestion}

The Constitutional Court decision Number $37 / P U U / / X / 2011$ should be the guideline for all parties, especially the IRC's and Supreme Court's judges. Therefore, it is important to establish an understanding at the judge's level in the Supreme Court that the process wage must be granted, calculated since the inception of the work termination dispute until the case is settled.

\section{References}

Ardian K, R. Nurman. Et.al. "Rekonstruksi Terhadap Sifat Final Dan Mengikat Putusan Mahkamah konstitusi, Jurnal Fiat Justitia. Vol. 10 Issue 4. October-December 2016. Pp. 789-814;

Arizona, Yance. "Dibalik Konstitusional Bersyarat Putusan Mahkamah Konstitusi". Jurnal Konstitusi PUSaKO Universitas Andalas. Vol. I No.1. November 2008. Pp.6-39;

Biky, Ahmad. Et.Al. 2014. David Vs Goliath (Pembelajaran kasus-kasus strategis di Bidang Perburuhan). Jakarta: LBH Jakarta;

Bintari, Aninditya Eka. "Mahkamah Konstitusi sebagai Negative Legislator dalam Penegakan Hukum Tata Negara", Jurnal Pandecta, Vol. 8 No. 1. January 2013, Pp.8490. DOI: 10.15294pandecta.v8i.2355;

Darmadi, Nanang Sri. "Kedudukan dan Wewenang Mahkamah Konstitusi dalam Sistem Ketatanegaraan Indonesia." Jurnal Hukum, Vol. XXVI. No. 2. August 2011. Pp. 667-690; 
Faiz, Pan Mohamad. "Relevansi Doktrin Negative Legislator", Majalah Konstitusi. No. 108. February 2016, Pp. 6-7;

Harun, Refly. “Implikasi Putusan MK Terhadap Proses Legislasi". Speech. Ceramah Perancangan Peraturan Perundang-undangan dengan tema "Implementasi Putusan MK terhadap proses legislasi Peraturan perundang-undangan", December 3, 2010;

Hidayat, Arif. "Penemuan Hukum Melalui Penafsiran Hakim dalam Putusan Pengadilan". Jurnal Pandecta. Vol. 8 No. 2. July 2013. Pp.154-169. DOI: 10.15294/pandecta.v8 i2.2682;

Indrayana, Denny and Zainal Arifin Mochtar, "Komparasi Sifat Mengikat Putusan Judicial Review Mahkamah Konstitusi Dan Pengadilan Tata Usaha Negara", Jurnal Mimbar Hukum, Vol. 19 No. 3. October 2007. Pp. 438-454;

Isra, Saldi and Feri Amsari. "Perubahan Konstitusi Melalui Tafsir Mahkamah Konsitusi." Jurnal Konstitusi PUSaKO Universitas Andalas. Vol. I No. 1. November 2008. Pp. 107-134;

Isra, Saldi. n.d. Negative Legislator. Available on website: https://www.saldiisra.we.id/ index.php/21-makalah/makalah1/302-neg ative-legislator.html. Accessed on February $17^{\text {th }}, 2018$;

Kapitan, Rian Van Frits. "Kekuatan Mengikat Putusan Constitusonal Review Mahkamah Konstitusi terhadap Mahkamah Agung", Jurnal Masalah-masalah Hukum. Vol. 44 No. 4. October 2015. Pp. 511-520;

Lailam, Tanto. "Penafsiran Konsitusi Dalam Pengujian Konstitusionalitas Undang-undang terhadap Undang-Undang Dasar 1945". Jurnal Media Hukum. Vol. 21 No. 1. June 2014. Pp.86-106;

Lumbuun, Topane Gayus. "Tindak Lanjut Putusan MK oleh DPR RI". Jurnal Legislasi Indonesia. Vol. 6 No. 3. September. 2009;

Monteiro, Yosef M. "Putusan Hakim dalam Penegakan Hukum Di Indonesia". Jurnal Hukum Pro Justitia. Vol. 25 No. 2. April 2007. Pp.130-138;

Prahassacitta, Vidya. "Makna Upah Proses Menurut Mahkamah Konsitusi Dibandingkan Dengan Beberapa Putusan Mahkamah Agung, kajian Putusan MK Nomor 37/PUU-IX/ 2011", Jurnal Yudisial. Vol. 6 No. 3. Dec- ember 2013. Pp.207-226. DOI: 10.29123/ jy.v6i3.99;

Prang, Amrizal J. “Implikasi Hukum Putusan Mahkamah Konstitusi", Kanun Jurnal Ilmu Hukum. No. 53 Year XIII. April 2011. Pp. 77-94;

Priono, Agus. "Penerapan Teori Penafsiran Hukum oleh Hakim sebagai Upaya Perlindungan Hukum Terhadap Notaris (Studi Atas Putusan Hakim Terhadap Tindak Pidana Akta Otentik)", Jurnal Pasca Sarjana Hukum UNS. Vol. V No. 2. July-December 2017. Pp.117-130;

Rahmah, Alef Musyahadah. "Hermeneutika Hukum sebagai Alternatif Metode Penemuan Hukum bagi Hakim untuk Menunjang Keadilan Gender". Jurnal Dinamika Hukum. Vol. 13 No. 2. May 2013. Pp. 293-306. DOI: 10.20884/1.jdh.2013.13.2.211;

Saldi Isra, "Peran Mahkamah Konstitusi dalam Penguatan Hak Asasi Manusia di Indonesia”, Jurnal Konstitusi, Vol. 11 No. 3, September 2014, Pp.410-427;

Salim, H. And Erlies Septiana Nurbaini. 2013. Penerapan Teori Hukum pada Penelitian Thesis dan Disertasi. Jakarta: PT. Raja Grafindo;

Siahaan, Maruaraar. "Peran MK Dalam Penegakan Hukum Konstitusi”. Jurnal Hukum. Vol. 16 No. 3. 2009, Pp.357-378;

Soemantri, Sri. 2004. Kedudukan. Fungsi dan Peran Konstitusi dalam Sistem Ketatanegaraan dalam Hukum dan Kuasa Konstitusi. Catatan-catatan untuk pembahasan RUU MK. Jakarta: KRHN;

Soeroso, Fajar Laksono. "Aspek Keadilan dalam Sifat Final Putusan Mahkamah Konstitusi", Jurnal Konstitusi. Vol. 11 No. 1. March 2014. Pp. 65-84;

Supratio, Steven. "Daya Ikat Putusan Mahkamah Konstitusi Tentang Testimonium De Auditu Dalam Peradilan Pidana". Jurnal Yudicial. Vol. 7 No. 1. 2014. Pp. 34-52. DOI: 10.29123/jy.v7i1.92;

Susanto, Mei. "Kewenangan Mahkamah Kontitusi sebagai Negative Bugdeter dalam Pengujian Undang-undang Anggaran Pendapatan dan Belanja Negara. Jurnal Konstitusi. Vol. 14 No. 4. Dec. 2017. Pp. 729-756;

Tutik, Titik TriWulan. 2010. Kontruksi Hukum Tata Negara Indonesia Pasca Amandemen UUD 1945. Jakarta: Kencana Prenada Media Group. 